\title{
The Concept of Criminal Law Interpretation under the Principle of a Legally Prescribed Punishment
}

\author{
Hong Wang \\ Liaoning Police College, Dalian, Liaoning Province, China
}

Keywords: Crimes, legality, legal principle, the explanation of criminal law

\begin{abstract}
For the understanding of a legally prescribed punishment, which cannot be blindly behavior of fact and law mechanically, stiff set of norms of criminal law text terms, more important is essentially consider legislative spirit, accurately understand the complete content of the norms of criminal law and method of boring purport. Sin the legal "sin", refers to the crime, the typed not simply refers to the crime on the implementation of specific forms, methods and steps. Explain the principle of legally prescribed punishment for a criminal law plays a complementary role, after explanation of criminal law, the content is clear, for the legally prescribed punishment for a possible. Which in our country there are many kinds of explanation of criminal law the main body, power source and the explanation content are not the same, and the explanation subject to exercise its powers are insufficient.
\end{abstract}

\section{Introduction}

The basic meaning of the principle of a legally prescribed punishment is: not expressly provided for sin, not expressly prescribed punishment law. Principle of a legally prescribed punishment conform to the trend of the development of democracy and the rule of law in modern society, the rule of law consciousness has been deeply rooted in modem countries, become the different social systems the most basic of the criminal law, one of the most important criteria.

\section{Principle of a legally prescribed punishment}

\subsection{The concept of the principle of a legally prescribed punishment.}

Principle of a legally prescribed punishment, also known as the doctrine of a legally prescribed punishment for a specified or legal doctrine, the meaning is: what is a crime, what crime, what is the condition of various kinds of crimes, what are the mitigation of the punishment mitigation, how to apply and how to calculate the specific sentencing range for each specific sin, are regulated by the criminal law [1]. Not expressly provided for sin is the method, the method has no clear stipulation is not crime, crime and criminal law must have the law, it is highly summarized the meaning of a legally prescribed punishment. The basic meaning of modern principle of a legally prescribed punishment is still the behavior of the event, is limited to behavior law with the law. Article 3 of the new criminal law in our country is specified by the principle: "law as a crime, convicted and punished in accordance with the law; Law does not expressly provide for crime, and may not be convicted and punished ".

The basic requirement of a legally prescribed punishment, that is, the court in determining whether a person what crime, and sentenced to punishment, must be in accordance with the clear provisions of the law, not at liberty to judgment [1]. Specifically, the law will be a kind of behavior is only for the crime, to this kind of behavior to be convicted. To determine whether a particular behavior constitutes a crime, the requirements and standards must be in strict accordance with the law, not in conformity with the requirements of the rules of law conditions and can't explain any, conjecture and guilt, and on the cognizance of the crime should also be in accordance with the provisions of the law, the law is what $\sin$ is $\sin$. At the same time, the crime punishment, namely what punishment and sentencing standards must be in strict accordance with the law, misdemeanor lenient sentence, felony heavy 
sentences, can't misdemeanor heavy sentences or felony lenient sentence.

\subsection{The content of the principle of a legally prescribed punishment.}

Law must be written, absolutely forbidden to apply common law, the written code of criminal law as the sole source of the criminal law and criminal law norms. For the behavior of the criminal law has not stipulated, not allowed by applicable habits to conviction sentencing [2]. By organs of state power released on the basis of the statute law, criterions for the conviction for the case justice judgment.

1) Prohibit any explanation. Any interpretation refers to the general citizens, social organizations, litigants, defender or agent, etc. According to own understanding, explained the law, and is one of the "informal", "official explanation" symmetrical [2]. Any explanation has no legal binding force. Any explanation shall be regarded as "the interpreter of law", although the way to understand and use the provisions of the criminal law, but the content of the accuracy and authority cannot be guaranteed, and without explanation power, does not have any effect. In our country formally interpreted as the legislative interpretation and judicial interpretation.

2) Ban after the event. Absolutely forbidden retroactive criminal law, the old principles as the only principle solves the problem of retrospective criminal law [2]. The actor behavior qualitative and punishment can only be based on behavior of effective law, promulgated after the new law has no retroactive effect. Law does not stand, the criminal law cannot ask each law is expected in the future, to the future of the criminal law to evaluation to guide people's behavior, cannot by its more. But in the new law ruling lighter case, use the old and lighter principle.

3) The ban is not a punishment on a regular basis. For punishment of the name, type, range must be confirmed by law, and the sentence must be absolutely sure, there is neither allow absolute not regularly, don't allow relative indefinite penalty rules.

4) The principle of clarity. I. what kind of behavior is a crime, the criminal law shall be sentenced to the punishment of the specific provisions must be made clear, no specific provisions of criminal law is considered invalid in violation of the legally prescribed punishment for a while. Clarity principle can be considered to be the most important principle of a legally prescribed punishment for a derivative principle [1]. Once the formulation requires implementation of criminal law, abstract and general law how to adapt to changing social reality, it will need to explain the criminal law.

5) Prohibit improper punishment behavior. Punishment of crime should be supported by clear according to criminal law, cannot be punished with no clear stipulation behavior and the guilty verdict, safeguard the offender's legitimate rights.

\subsection{The role of the principle of a legally prescribed punishment.}

The realization of the principle of a legally prescribed punishment, is helpful to the accurate implementation of the criminal law, the "ought to" laws apply to all types of cases, the criterions for the conviction of the role of the "reality". Strengthening the guidance of criminal law and the roles of evaluation and prediction are effect. Also ensure the implementation of the criminal law enforcement function and education function [3]. Principle of a legally prescribed punishment is also a guarantee of human rights, using the right of punishment in accordance with the law; punish the criminal protection of human rights, and through the law governing the rights of criminal law, to prevent the abuse of penalty power, to safeguard human rights by positive and negative two aspects.

\section{Criminal law interpretation under the principle of a legally prescribed punishment of The reason why for criminal law interpretation.}

Explanation of criminal law is made by legislatures for reasonable, legal interpretation of the criminal law provisions, the things that make hidden in the law, make not clear content becomes clear. Criminal laws provisions of a certain level of abstraction and stability, and comprehend the legislative intention in the correct criminal law interpretation, the necessity of accurately apply the law. The law needs to explain reached a consensus around the world. Legal interpretation is one of the basic concepts of the traditional theory of law [3]. Legal interpretation is made a new structure of legal process, it contains three elements: 
1) Explain: interpreter is thinking, logical, creative and are endowed with the power of interpretation of the person or organization;

2) Explain objects: explain the object of law and legal facts, to explain the law and reality to achieve the fusion;

3) The explanation and explain the relationship between objects: can neither fully the subjectification of nor objective.

The specific reasons for the explanation of criminal law are as follows:

1) The vitality of law lies in implementation, the implementation of the law lies in the interpretation of the French, interpretation and application. Use the law ought to be to the reality of social life, must go through the understanding of the law, interpretation and application.

2) The criminal law is the basic task of criminal law and criminal behavior, activist judges is the premise of the understanding of criminal law, interpretation and application [4]. Any law in the actual application process always facing explain problems, all need people to have a correct understanding of the law. The interpretation of the criminal activities to ensure the uniformity of the legal content through the statutory principle of crime in order to facilitate the same cases across the country to reach the same decision, safeguard the rights of people.

3) Show that the existence of the criminal law form for the abstract, general, is a specification for general people and things, so in the specific case for there is certain gap, only through explanation, to become the specific standards of behavior. Even stating the charges can't be in the law of all the legal implications to explain, it makes the provisions of the criminal law only on the general characteristics of crime and punishment has carried on the summary and description, if want justice of judicial activities or for a specific interpretation of the law through the theory and practice [4].

4) The criminal law, as well as other laws, is expressed with language, language expression ability is limited [4]. Objective phenomena in the world is complicated, human language has the characteristics of limited, it is hard to perfect to describe everything accurately, then you need to appropriate explanation to reveal its true content.

5) The criminal law created by lawmakers drawn up under the social environment at that time, the law has certain stability and real life is always growing, therefore the law always has the characteristics of hysteresis. Behind the law need to be interpreted with real life, to adapt to changing social needs [5]. Law can't change often, while social advancement and can't stop the footsteps, the contradiction between the stability and development can only be solved by legal interpretation.

6) It is based on lawmakers to the understanding of the social norms of criminal law legislation. Lawmakers' understanding of the objective social, experiences and feelings to its content and direction of criminal law has a certain understanding [5]. But although this knowledge based upon reflect of social objective, lawmakers him as though living in the objective society, but it is contained in word and deed of his own subjective mind. Any behavior cannot be completely objective, people more or less have some his heart factors with which the law is no exception, so its legal interpretation is needed to be corrected.

\section{The body of the criminal law explanation}

\subsection{Legislative interpretation.}

The meaning of the legislative interpretation of criminal law refers to the legislature explained. The legislature has the legislative power, of course, also have the right to explain the law, and this explanation has the same legal force and legislation. Criminal legislative interpretation to make up for the loopholes in the norms of criminal law, make to adapt to the complex and changeable norms of criminal law and criminal activities, to maintain the stability of the norms of criminal law, plays an important role [5]. Criminal law enacted in 1997, our country began to pay attention to the legislature to pass legislation to explain further clear legislative purpose. Especially to the problems of the judicial organs, explain through legislation to clear them. The two problems of the supreme people's court has made judicial interpretation, there are different opinions of the supreme people's procurator ate, and thus a legislative interpretation of the National People's Congress (NPC). The legislative 
explanation for legislative intention clear law, further standardize judicial interpretation is of great significance.

\subsection{Judicial interpretation.}

Judicial interpretation refers to the judicial organs to explain the meaning of the criminal law of the multi-function. In the criminal law applicable, often appear some problems, needs to be clear on the through judicial interpretation. Therefore, the judicial interpretation of criminal law correctly apply is of great significance.

In addition, the supreme people's court and the supreme people's procurator ate jointly with the relevant administrative departments of the problems in the criminal law applicable to explain; it can be regarded as a quasi judicial interpretation [4]. Our country's judicial interpretation in terms of content, and can be divided into normative interpretation and case interpretation. Normative interpretation is usually in the form of the regulations, "explain" and so on, and case interpretation is often in form of "approval", "reply" and so on. In addition, there is in the form of symposium summary of judicial explanatory file, also has the nature of the judicial interpretation, only slightly less formal judicial interpretation on the legal effect. Based on December 16, 2001, the supreme people's court, the supreme people's procurator ate on the problem of criminal judicial interpretation time provisions shall be applicable, the provisions of article 2 "for the judicial interpretation occurred prior to implementation of behavior, behavior of no relevant judicial explanation, has not yet been processing or after the enforcement of judicial interpretation in handling cases, in accordance with the provisions of the judicial interpretation [6]. But former guide judicial interpretations stipulated in article 3 "for the new judicial interpretation, occurred prior to implementation of behavior existing relevant judicial explanation, according to the behavior of the judicial interpretation, but for the new judicial interpretation for criminal suspects, apply the new judicial interpretation. "Therefore, in the case of with old and new judicial interpretation, shall, according to the principle of the old and be given a lighter to solve the problem of the time the judicial interpretation.

\section{Explanation of criminal law and the principle of a legally prescribed punishment for a relationship}

Criminal law explanation is that the understanding and interpretation of the criminal law provisions will expand the content of the criminal law provisions, downsizing and specific. And in the judicial practice, legal interpretation of the applicable legal is provisions. Some people think that the legal interpretation on the effectiveness of offside is on the principle of a legally prescribed punishment for a shake [6]. But the criminal law provisions of mechanical execution may have made the dogmatism mistake. Explanation of criminal law and the principle of a legally prescribed punishment is not the opposite two levels, the talk of a legally prescribed punishment is not means no judicial explanation, this view is a kind of rigid way of thinking. Too much emphasis on "law" in the principle of a legally prescribed punishment, and ignore the value of the method and purpose.

Criminal law explanation is a re-creation of the criminal law provisions on people's behavior standard, is one of the legal bases of legal crime, is an important complement of crime legal [7]. Legality as a guiding principle of the criminal legal system in China, is the specific cases arising in the course of social important methods, criterions for the conviction of the criminal law provisions of abstract and hysteresis characteristics and its high degree of generality cannot meet the daily all kinds or simple or complicated cases in the judicial practice of the specific conditions, this requires a certain flexibility to supplement the guidance of the criminal law explanation just have this function, and thus become the important supplement of a legally prescribed punishment.

Under the high speed development of modern society, politics, economy, social relationship is very complicated and change quickly, strict legislation, again also cannot contain all the legal problems arising from the society [7]. The generation of new things and the establishment of new social relations self-built, make the enacted law problems, omissions blank, even need to show the judicial organs in the judicial practice, supplement and perfect, to make the law conforms to the development of the society, which make it possible for the realization of the statutory principle of 
crime. Legal interpretation is the description and interpretation of the enacted law and law is complementary relationship. Law has certain stability and real life is always growing, therefore the law always has the characteristics of hysteresis [7]. The stability of the law and abstractness make explanation of criminal law has become inevitable, through the explanation of criminal law, can make the content of the hidden in the criminal law provisions of, make it clear not clear provisions, to continue to use from the provision of social life.

\section{Summary}

A successful interpretation often depends on the use of the correct interpretation. Not according to their own tastes and preferences to select four different types of explanation, the different behaviors must be unified, explain will work. However, sometimes this account status is prominent, sometimes is another explanation, only a comprehensive consideration of various factors in this direction cannot be changed. - in the form of explanation theory focuses on semantic interpretation, but the essence of interpretation theory pay attention to the objective interpretation. As the goal of legal interpretation and legal purpose is to explore, as the goal of legislative interpretation is the subjective meaning when lawmakers specification, there are legal norms or the objective meaning, has formed the theory of subjective interpretation and objective interpretation. Therefore, to consider a variety of interpretation methods, adhere to the purpose of interpretation in a variety of interpretation of the prominent role, for the solution of the case, to achieve the goals of law have very big effect.

\section{References}

[1] J. B. Liang, Criminal law, Beijing: China legal publishing house, 2002, vol. 5, pp. 40-44.

[2] X. H. Jiang, Explanation of criminal law limits theory, The study of law, 2005, vol. 4, pp. 87-89

[3] Y. Y. Hu, Legally prescribed punishment for a sight of the criminal law interpretation, The Chinese law, 2004, vol. 3, pp. 25-28.

[4] R. B. Zhu, The basic principles of criminal law interpretation, Law research, 1997, pp. 25-28.

[5] M. J. Zhang, Principle of a legally prescribed punishment and legal interpretation method, East China criminal judicial review, Beijing: law press, 2003, pp. 14-17.

[6] X. L. Chen, Doctrine of a legally prescribed punishment, Beijing: China legal publishing house, 2010, pp. 232-233.

[7] G. L. Liang, In fact of a crime and expected possibility, Chinese and foreign law, 2003, vol. 3, pp. 43-46. 